\title{
The Effect of Direct Instruction Strategy and Students' Social Interaction on Learning Achievement of Pancasila and Civic Education
}

\author{
Evi Susilawati ${ }^{1}$, Harun Sitompul ${ }^{2}$, Julaga Situmorang ${ }^{3}$ \\ Universitas Islam Sumatera Utara, Indonesia ${ }^{1}$ \\ Universitas Negeri Medan, Indonesia ${ }^{2,3}$ \\ evi.utnd@gmail.com
}

\begin{abstract}
The purpose of this study was to look at the effect of learning outcomes of Pancasila and Civic Education based on students' social interactions using the Direct Instruction (DI) strategy on students of SMP Negeri I Labuhan Deli, North Sumatra Province in the 2015/2016 academic year. The population of this research was 377 students and the sample was 77 students. The sampling technique uses cluster random sampling. Data collection methods in this study were obtained using student learning outcomes tests and hypothesis testing using Anava. Before the hypothesis test was performed, the data analysis test prerequisites were done using the normality test and homogeneity test. From the two prerequisites that had been made it can be seen that the data comes from a normally distributed population and the sample comes from the same variant, then a hypothesis test can be performed. Based on the research's hypothesis test shows that the average learning outcomes of Pancasila and Civic Education of students taught using DI learning strategies in students who have social interaction characteristics of cooperative students is 66.70 , and who have social interaction characteristics of competitive type students is 74.806 . Hypothesis testing results show that the learning outcomes of Pancasila and Civic Education of students taught using the DI strategy on social interaction characteristics of competitive students is higher than students who have social interaction characteristics of cooperative students.
\end{abstract}

Keywords: Direct Instruction Strategy, Social Interaction Student, Learning Achievement of Pancasila and Civic Education.

\section{Introduction}

Industrial Era 4.0 will bring many changes that can not be dammed. The urgency is that if the state needs to make maximum efforts and be more vigorous in giving understanding to all elements of society about the nature of the industrial revolution 4.0 era with all its logical consequences, then the state must take the initiative to encourage all elements of society to be more concerned with changes and challenges that occurred in the industrial revolution era 4.0. Preparing millennials to have cooperative and competitive behavior in the industrial revolution 4.0era is also an urgent need. The essence of the industrial revolution 4.0 is a cultural revolution, human revolution in various aspects of life not only a revolution in technology, but a revolution in social behavior and cultural behavior [3]. It is very important for the learning activities of 
Pancasila and Civic Education to meet the challenges and needs of the current era of the industrial revolution 4.0. Pancasila and citizenship education learning can help millennial generation to gain knowledge to become more competitive students in their field. Pancasila and citizenship education can encourage the improvement of human resource competencies in Indonesia that are skills for competitiveness in all fields. Furthermore, the industrial revolution 4.0 is faced with economic challenges with the growing need for cooperation and collaborative in terms of: (1) compromising and cooperative skills, (2) ability to cooperate in teams, (3) communication skills, and (4) networking skills [10].

This challenge shows how important it is to develop social interaction of cooperative and competitive types of students in learning Pancasila and Civic Education. A number of studies have shown that social interactions of cooperative type students in learning activities can optimize student participation in learning, give more time to students to think, discuss, and assist students in developing concepts in the subject matter that is in them [9]. Likewise, the need for social interaction of cooperative type students is very necessary because the changing world is now entering the era of the industrial revolution 4.0 which demands that schools must prepare quality graduates and be able to compete globally is important for everyone and important for the future of a country [7]. Thus, the support and role of education is expected to increase the competitiveness of the Indonesian people in the midst of the global competition of the rapid development of the industrial revolution 4.0. In the era of industrial revolution 4.0 found the phenomenon of low levels of student motivation in competing caused by mental weakness and personality of the younger generation to be able to excel, courage to take risks, tenacity, struggle, self-confidence, creativity, and innovation. However, to develop social interaction of students in cooperative and competitive types requires a learning activity that can provide an interesting learning experience and have a creative effect on student learning. This is influenced by the learning strategy used by the teacher. Symptoms that can be seen in the learning process at SMP Negeri 5 Labuhan Deli, Deli Serdang Regency, so far most of the teachers in the Pancasila and Civic Education subjects did not help students develop these two types of social interaction. Therefore we need a learning strategy that is able to help students to be able to easily understand the subject matter being studied [4]. The learning strategy in question is the Direct Instruction (DI) strategy.

The DI strategy is a strategy that uses the smallest possible number of examples to produce as much learning as. The advantage of the DI strategy is to provide a guide for each student to interact with the physical environment directly. This physical environment strengthens and gives different responses to each student. In the DI strategy, the teacher as an intelligent adult is the learning environment that is closest to students and is around students. In this case, the teacher as the most effective model and can arrange and rank student learning experiences by teaching concepts and problem-solving skills better than other models because the teacher is the only standard of behavior that students must emulate.

The design of the DI strategy has significantly increased school success in teaching various skills to students. The DI strategy applied in this study is a learning strategy that guides students to learn the Pancasila and Civic Education material by the teacher using examples rather than examples. By using the DI strategy, social interaction of cooperative and competitive type students will be built up and students will be maximized, more active and focused in learning, students will experience firsthand so students' understanding of the material can be measured in a structured way. The use of DI strategies makes learning Pancasila and Civic more effective. 


\section{Direct Instruction (DI) Learning Strategy}

Learning strategies contain action plans or a series of learning activities including the use of methods and use of various resources or strengths in learning that are structured to achieve learning objectives effectively and efficiently. In order to achieve these objectives, various forms of learning strategies are used. One of the forms of learning strategies is the direct instruction strategy. The DI strategy has an empirical basis derived from Piaget's theory with behavioristic learning flow about cognitive processes and response stimuli which holds that learning depends on the stimulus response process including giving feedback [8]. The application of Piaget's theory in learning is giving reinforcement and feedback to students in learning [15].

Limitation of DI strategy as a strategy that presents lessons through verbal speech or direct explanation to students are in the form of examples and not examples [13]. Another understanding of the DI strategy is a learning strategy carried out through face-to-face between teachers and students with learning information sources using scripts with well-structured learning steps [14]. Face-to-face activities in direct learning strategies are a set of teacher actions to support student learning processes, taking into account internal and external events that can be known or predicted during the face-to-face process. Before students learn further information and skills, they must first master the basic information and skills provided in the form of examples and not examples. For the acquisition of basic information and skills requires an interesting classroom management and maintain student attention from the beginning until the completion of the learning process. In this case the teacher must pay close attention to the formulation of learning objectives and assignments given to students. The dominance of the teacher is very important in implementing the direct learning strategy. When implementing this learning strategy, the teacher must demonstrate knowledge and skills in the form of examples and not examples contained in the text that will be trained to students [12].

Direct learning strategy is a strategy of presenting lessons done by the teacher using the lecture and question and answer method to transfer all the knowledge he has. The process of transmitting knowledge from the teacher to students is due to 2 (two) objectives of using direct learning strategies namely (1) knowledge by description, namely: the transmission of student knowledge is described from those who have learned first from students; (2) knowledge by acquantance, namely: the ability to receive knowledge obtained by students themselves accurately [11]. The role of the teacher in direct learning is very dominant according to the teacher center paradigm. In the teacher centered paradigm, the teacher's presence is crucial in the ongoing learning process. The presence of teachers in class is related to the importance of the teacher's attention in managing the class because the teacher also plays an important role in fostering a positive class climate such as: regulating the tempo of learning, smooth learning flow, maintaining order and the presence of students in class, and fast handling in the event of deviations student behavior [2]. The DI strategy has unique characteristics seen in Table 1 below: 
Table 1. Characteristic of DI Strategy

$\begin{array}{lc}\text { Theme } & \text { DI Strategy } \\ \text { Theory } & \text { Direct Instrtuction Strategy }\end{array}$

\begin{tabular}{|c|c|}
\hline Approach & Teacher Centered \\
\hline $\begin{array}{l}\text { Teaching-Learning } \\
\text { Main Objectives }\end{array}$ & $\begin{array}{l}\text { 1. Every student who is economically disadvantaged can catch up with } \\
\text { their peers who are more economically fortunate if they are given } \\
\text { effective and efficient learning. } \\
\text { 2. Formation of students' basic academic skills } \\
\text { 3. Development of students' conceptual skills } \\
\text { 4. Development of cognitive aspects of students } \\
\text { 5. Development of affective aspects, especially on self-actualization } \\
\text { 6. Develfopment of student academic performance }\end{array}$ \\
\hline Class & $\begin{array}{l}\text { 1. Students of the same age } \\
\text { 2. Students with small group learning with groups of 5-10 people } \\
\text { 3. All students in the class are taught the same material } \\
\text { 4. Learning takes place in the classroom }\end{array}$ \\
\hline Teaching Steps & $\begin{array}{l}\text { 1. Conveying goals and preparing students } \\
\text { 2. Demonstrating knowledge and skills } \\
\text { 3. Guiding students } \\
\text { 4. Check understanding and feedback } \\
\text { 5. Provide an opportunity to repeat the material and application }\end{array}$ \\
\hline Teaching Method & $\begin{array}{l}\text { 1. Direct learning with the lecture method } \\
\text { 2. Direct learning with the question and answer method } \\
\text { 3. Direct learning with methods using examples and not examples } \\
\text { 4. Direct learning with simple training methods } \\
\text { 5. Direct learning with the method of responding together } \\
\text { 6. Learning is carried out in a structured manner } \\
\end{array}$ \\
\hline Teaching Materials & $\begin{array}{l}\text { 1. Learning based on textbooks and learning script guides } \\
\text { 2. Learning resources are textual in the form of texts using examples } \\
\text { and not examples }\end{array}$ \\
\hline Content & $\begin{array}{l}\text { 1. Memorize facts and objective information } \\
\text { 2. The process of developing cognitive structures } \\
\text { 3. Development of the basic concepts of an object } \\
\text { 4. Development of combined knowledge is knowledge about the } \\
\text { change of an object } \\
\text { 5. Development of complex knowledge of an object }\end{array}$ \\
\hline Social Aspects & $\begin{array}{l}\text { 1. The intensity of students' social interactions is constant } \\
\text { 2. The teacher is considered as an example to be followed } \\
\text { 3. Students must obey the teacher's instructions. }\end{array}$ \\
\hline $\begin{array}{l}\text { Curriculum } \\
\text { Implementation }\end{array}$ & $\begin{array}{l}\text { 1. The teacher conducts learning activities based on an existing } \\
\text { curriculum } \\
\text { 2. The curriculum is usually implemented in an integrated manner for } \\
\text { all students, regardless of students' abilities or interests. } \\
\text { 3. The contents of the lesson are generally linear } \\
\text { 4. Each student receives units of study at the same speed in the same } \\
\text { context }\end{array}$ \\
\hline
\end{tabular}

Referring to the characteristics of the DI strategy, the use of the DI strategy in the Pancasila and Citizenship Education subjects in this study uses the following steps: (1) Step 1: In step 1 this is the activity of conveying objectives and preparing students with the activities carried out 
by the teacher is to convey Citizenship Education learning objectives, lesson background information, the importance of students learning the material to be delivered, and preparing students for learning; (2) Step 2: In step 2 this is the teacher's activity in demonstrating knowledge and skills by presenting information step by step and using examples and not examples; (3) Step 3: In step 3 this is the activity of guiding students; (4) Step 4: In step 4 this is the activity of checking student understanding and feedback; (5) Step 5: In step 5 this is an independent training activity in which the activities carried out by the teacher are to provide opportunities to repeat the material and apply the material to more complex situations.

\section{Students' Social Interaction}

Social interactions that occur in learning activities are interactions that occur between teacher and students, and between students and students. These social social interactions of students are social interactions within the study group because each student as a group member is interdependent with each other, and at least they have the potential to carry out social interactions with each other. Through social interaction within the group, not only does the transfer of knowledge but friendship, the student community occur, so that it forms a social system that leads to the integration of students and all of that will affect student learning outcomes both cognitive, affective, and psychomotor learning outcomes. Related to the social situation of students in social interaction with their friends students often engage in prosocial behavior. Sometimes, students as individuals in groups interact in a cooperative type where they help each other, share information, and work together for mutual benefit and interact interactively where they outperform and compete with one another. The social type of social interaction of the cooperative type students is shown through cooperative relationships while the social interaction of students of the competitive type is shown through competitive relationships.

This cooperative type of social interaction is important in the learning activities of Pancasila Education and Nationality because schools are a place for students to try to cooperate with each other. Cooperative type student social interaction becomes a necessity for students to improve their learning outcomes. Cooperative type student social interaction is needed in terms of: (1) working together to achieve common goals; (2) students in groups interact with each other sharing ideas and information, seeking additional information, making decisions on their findings throughout the class; learning that fosters collaboration towards a strong emphasis on learning goals rather than on performance goals which encourages teachers to use alternative assessment techniques; and (3) through working together can help improve student achievement and retention, increase self-esteem and intrinsic motivation as well as develop more positive attitudes towards learning abilities and social skills. Likewise in the social interaction of competitive type students developed at school will have an impact on the following things: (1) increasing student independence in completing their assignments, (2) trying to get the best value in order to obtain recognition from others, (3) always expressing independent ideas to be always appreciated by others, (4) students can still work in their groups even though faced with competition between group members and competition with other groups, and competition situations like this can be the most effective way to make the class more productive, (5) each student who is joined in a group will form their own subgroups and always strive to be the best in their groups to obtain awards or prizes [6].

\section{Pancasila and Civic Education Learning Achievement}

Pancasila and Civic Education subjects are subjects that consist of a series of processes to direct students to become citizens of Indonesian national character, intelligent, skilled and 
responsible so that they can play an active role in society in accordance with the provisions of Pancasila and the 1945 Constitution. These definitions can be broken down into 2 (two Pancasila and Civic Education subjects objectives namely: (1) general objectives consisting of: (a) civic confidence, civic commitment, and civic responsibility; (b) knowledge of civic; (c) civic skills including civic competence and civic responsibility; (2) specific objectives consisting of the ability of students in terms of: (a) displaying a character that reflects the appreciation, understanding, and practice of values and morals of Pancasila personally and socially; (b) has constitutional commitment supported by a positive attitude and a full understanding of the 1945 Constitution of the Republic of Indonesia; (c) think critically, rationally, and creatively and have a national spirit and love for the motherland imbued with Pancasila values, the 1945 Constitution of the Republic of Indonesia, the spirit of Unity in Diversity, and the commitment of the Unitary Republic of Indonesia, and (d) participate actively, intelligently, and responsibly as members of the community, the nation's budding, and citizens in accordance with their dignity and dignity as creatures created by God who lives together in various socio-cultural settings [1].

PPKn subjects are developed as a conductive social order or provide an atmosphere for the development of various personal qualities of students. Junior High School is a level of primary and secondary education which is an integral part of the community that needs to be developed as a center for lifelong student culture and empowerment, which is able to set an example, build willingness and develop student creativity in the process of democratic learning.Empowering students who are able to set an example and develop student creativity in the democratic learning process reflects the students' learning achievement of Pancasila and Civic Education. The learning outcomes of Pancasila and Civic Education are defined as a set of knowledge for students' understanding of various civic discourses; have democratic and responsible behavior, and have good character and personality, in accordance with the norms that apply in the life of society and the state. Aspects of learning achievement for Pancasila and CivicEducation in the form of civic competencies are described as follows: (a) civic knowledge competencies involving academic-scientific abilities developed from various political, legal and moral theories or concepts; (b) civic skills include intellectual skills and participatory skills in the life of the nation and state; and (c) the character or character of citizenship (civic dispositions) which is the estuary development of the two competencies above, namely: citizenship knowledge and citizenship skills.

Learning achievements of Pancasila and Civic Education in the form of civic knowledge can be seen from the ability of the Pancasila and Civic Education material mastered by students which includes knowledge about the rights and responsibilities of citizens, human rights, principles and processes of democracy, government and non-government institutions, national identity, government based on rule of law, and free and impartial justice, the constitution, and the values and norms in society. Student civic skills learning achievements can be seen from intellectual skills and participatory skills in the life of the nation and state owned by students. While learning outcomes in the form of civic dispositions can be seen from the character of students in terms of behaving in the community which is shown by virtuous behavior and good civic character. Thus students as citizens first need to have good civic knowledge, especially knowledge in politics, law, and morals in the life of the nation and state.

Furthermore, students as good citizens are expected to have intellectual and participatory skills in the life of the nation and state. In the end, knowledge and skills will form an established character or character, so that it becomes an attitude and habit of daily life. Character or daily life habits that reflect good citizens such as religious attitude, tolerance, honesty, fairness, democracy, respect for differences, respect the law, respect the rights of others, have a strong 
national spirit, have a sense of social solidarity, and other attitudes. These characters must be displayed in the form of educational programs carried out in curriculum activities in schools.

\section{Research Methods}

This research is quantitative research with a descriptive approach. The research method uses the experimental method. This research was conducted in the 2015/2016 academic year at State Junior High School (SMPN) 1 Labuhan Deli, Deli Serdang Regency, which is located at Jalan Veteran Pasar IV, Deli Serdang Regency. The research treatment was carried out by adjusting the school lesson schedule. Provision of treatment carried out during 11 (eleven) meetings. The 1st meeting (First) held a pretest. The second meeting (two) provides a questionnaire for student social interaction. The third meeting up to the 10th meeting conducted treatment, while the 11th (eleventh) meeting held a final test. It was held each week with 1 (one) time face-to-face with $3 \times 40$ minutes learning time.

This research was conducted at SMP N 1 Labuhan Deli of class VII (seven) SMP Negeri 1 Labuhan Deli, Deli Serdang Regency, the population are ten classes with 377 students. The sampling technique in this study uses Cluster Random Sampling, which is a sampling technique with each element of the population having the same opportunity and is known to be selected [5]. The sampling method in this study was done by writing the class name on the rolled-up paper then randomly selected as the treatment class applying the DI strategy with a group of students who have social interaction characteristics of cooperative and competitive type students as many as 77 people. The curriculum used in this study is Curriculum class VII on second semester.

\section{Result and Discussion}

The normality test data check is used to find out if the sample is from a normally distributed population. Testing is done using the Lilliefors Test on eight groups of samples. A summary of the results of normality calculations can be seen in Table 3 below:

Table 3. Summary of Data Normality Calculation Results

\begin{tabular}{clccc}
\hline No & \multicolumn{1}{c}{ Group } & dk & $\mathbf{L}_{\text {hitung }}$ & $\mathbf{L}_{\text {tabel }}$ \\
\hline & $\begin{array}{l}\text { Learning achiement of Pancasila and Civic Education in DI strategy } \\
\text { classes }\end{array}$ & 77 & 0,075 & 0,101 \\
2 & $\begin{array}{l}\text { Pancasila and Civic Education learning achiements on the } \\
\text { characteristics of cooperative students' social interaction }\end{array}$ & 02 & 0,070 & 0,098 \\
3 & $\begin{array}{l}\text { Pancasila and Civic Education learning achiements on the } \\
\text { characteristics of cooperative students' social interaction }\end{array}$ & 0,096 & 0,104 \\
4 & $\begin{array}{l}\text { Pancasila and Civic Education learning oachiement in the DI strategy } \\
\text { class with the characteristics of cooperative type student social } \\
\text { interaction. } \\
\text { Pancasila and Civic Education learning oachiement of DI class } \\
\text { strategies with the characteristics of social interaction of competitive } \\
\text { type students }\end{array}$ & 36 & 0,113 & 0,138 \\
\hline
\end{tabular}


From table 3 above it is obtained that the PPKn learning outcomes data in the DI strategy class is normally distributed. This is known from the magnitude of Lhitung $<$ Ltable at a significance level of $5 \%$, ie $(0.075<0.101)$. Learning outcomes of Pancasila and Civic Education of cooperative type student social interaction is normal distribution type. This is known from the large Lhitung $<$ Ltable at a significance level of $5 \%$, namely $(0.070<0.098)$. Data on learning outcomes of Pancasila and Civic Education on the characteristics of social interaction of competitive type students are normally distributed. This is known from the magnitude of Lhitung $<$ Ltable at a significance level of $5 \%$, ie $(0.096<0.104)$. PPKn learning outcomes data on the social interaction characteristics of cooperative type students in the DI strategy class were normally distributed. This is known from the magnitude of Lhitung $<$ Ltable at a significance level of $5 \%$, ie $(0.113<0.138)$. Data on learning achiements of Pancasila and Civic Education on the characteristics of social interaction of competitive type students in the DI strategy class are normally distributed. This is known from the magnitude of Lhitung $<$ Ltable at a significance level of $5 \%$, ie $(0.117<0.148)$. Furthermore Homogeneity test results can be seen in the following Table 4 :

Table 4. Summary of Data Homogeneity Test Calculation Results

\begin{tabular}{|c|c|c|c|c|c|}
\hline No & Group & $\mathbf{N}$ & Average & $\begin{array}{l}\text { Standard } \\
\text { Devias }\end{array}$ & Varians \\
\hline 1 & $\begin{array}{l}\text { Learning achiement of Pancasila and Civic Education in DI } \\
\text { strategy classes }\end{array}$ & 77 & 70,532 & 10,853 & 117,788 \\
\hline 2 & $\begin{array}{l}\text { Pancasila and Civic Education learning achiements on the } \\
\text { characteristics of cooperative students' social interaction }\end{array}$ & 82 & 71,390 & 10,996 & 120,912 \\
\hline 3 & $\begin{array}{l}\text { Pancasila and Civic Education learning achiements on the } \\
\text { characteristics of cooperative students' social interaction }\end{array}$ & 77 & 74,736 & 8,876 & 78,783 \\
\hline 4 & $\begin{array}{l}\text { Pancasila and Civic Education learning oachiement in the DI } \\
\text { strategy class with the characteristics of cooperative type } \\
\text { student social interaction. }\end{array}$ & 41 & 66,780 & 10,880 & 118,374 \\
\hline 5 & $\begin{array}{l}\text { Pancasila and Civic Education learning oachiement of DI class } \\
\text { strategies with the characteristics of social interaction of } \\
\text { competitive type students }\end{array}$ & 36 & 74,806 & 9,101 & 82,828 \\
\hline
\end{tabular}

Referring to Table 4, it can be seen that the data on learning outcomes of Pancasila and Civic Education obtained homogeneity tests were carried out using the F Test and the Barlett Test. Based on the calculation of homogeneity obtained data on learning outcomes of Pancasila Education and Citizenship in the DI strategy class is homogeneous. This is known from the large Fcount $<$ Ftable at a significance level of $5 \%$, ie $(1,501<1.82)$. Thus it can be concluded that the distribution of Pancasila and Civic Education learning outcomes in the DI strategy class is homogeneous. Furthermore, it is known that the Pancasila and Civic Education $\mathrm{n}$ learning outcomes data on the social interaction ability of cooperative type students and the characteristics of social interaction of competitive type students is homogeneous. This is known from the large Fcount $<$ Ftable at a significance level of $5 \%$, ie $(1.535<1.82)$. Thus, it can be concluded that the distribution of Pancasila and Civic Education learning achiement data on the characteristics of social interaction of cooperative type students and the characteristics of social interaction of competitive type students is homogeneous. From the two prerequisites above it can be seen that the data comes from normally distributed populations and the samples come from the same variants, then the next hypothesis test can be performed which can be seen in Table 5 below: 
Table 5. Summary of Data from Descriptive Analysis Calculation Results

\begin{tabular}{lcr}
\hline Students' Social Interaction & \multicolumn{2}{c}{ Direct Interactions Strategy } \\
\hline \multirow{4}{*}{ Cooperative Type } & $\mathrm{N}$ & 41 \\
& $\sum \mathrm{X}$ & 2,738 \\
& $\sum \mathrm{X}^{2}$ & 187,698 \\
& $\overline{\mathrm{X}}$ & 66,780 \\
& $\mathrm{~s}$ & 10,880 \\
& $\mathrm{~N}$ & 36 \\
Competitive Type & $\sum \mathrm{X}$ & 2,693 \\
& $\sum \mathrm{X}^{2}$ & 204,433 \\
& $\overline{\mathrm{X}}$ & 74,806 \\
& $\mathrm{~s}$ & 9,101 \\
\hline \multirow{3}{*}{ Total } & $\mathrm{N}$ & 77 \\
& $\sum \mathrm{X}$ & 5,431 \\
& $\sum \mathrm{X}^{2}$ & 392,131 \\
& $\overline{\mathrm{X}}$ & 70,532 \\
\hline
\end{tabular}

Based on table 5 above, it can be seen that the average learning achiement of Pancasila and Civic Education taught using the DI strategy on the social interaction characteristics of cooperative type students is 66.70 , while students taught with the DI strategy on the social interaction characteristics of competitive type students are 74,806 . This shows that the learning outcomes of Pancasila Education and Civic students who are taught by using the DI strategy on the characteristics of social interaction of competitive type students is higher than students who have social interaction characteristics of cooperative type students. There is a significant difference between the students' learning achiement of Pancasila and Civic that have cooperative type social interaction characteristics and competitive type social interactions taught using the DI strategy from the findings of this study prove that direct learning strategies have been tested to improve students' learning achievement of Pancasila and Civic Education.

This proves that learning Pancasila and Civic Education using DI strategies is suitable for students who have characteristics of social interaction of competitive type students. Pancasila and Civic Education learning activities for students who have the characteristics of competitive type social interaction taught using the DI strategy want to master the learning material of Pancasila and Civic Education on their own abilities and try to outperform each other in learning activities. With such learning activities, the acquisition of Pancasila and Civic Education learning achievement can be achieved to the maximum because the DI strategy requires each student to deal with assignments individually and condition the learning activities from the beginning of the learning activities to the end of the learning activities to be able to compete with their peers the first to master the subject matter and to obtain the best learning achievement of Pancasila and Civic Education.

\section{Acknowledgements}

Writers would like to express their deepest gratitude to: (1) Rector of Medan State University, along with his staff, (2) Director of Postgraduate of Medan State University, along with his Staff, (3) Head of the Study Program of Doctor of Education Technology in Medan State University, along with his Staff , (4) Rector of the Islamic University of North Sumatra, 
along with his staff, (5) Dean of the Faculty of Education and Education of the Islamic University of North Sumatra, and their staff, may God Almighty give them health.

\section{References}

[1] A. Rahman, Srijanti. \& Purwanto, H.I. Pendidikan Kewarganegaraan Di Perguruan Tinggi. Mengembangkan Etika Berwarganegara. Jakarta : Salemba Empat. p 77. (2010).

[2] Barksdale, Christopher J. Examining The Relationship Between Clasroom Climate and Student Achievement of Middle School Students. Published Disertation. Clear Lake: University Of Houston. p 55. (2017).

[3] Beritasatu. Revolusi Industri 4.0 Harus Dibarengi Perubahan Perilaku, https://id.beritasatu.com. Accessed on $30^{\text {th }}$ December (2018).

[4] Buchori, Achmad. et al. Effectiveness of Direct Instruction Learning Strategy Assisted by Mobile Augmented Reality and Achievement Motivation on Students Cognitive Learning Results. Asian Social Science. Vol. 13 (2017).

[5] Indrawan, Rully. \& Yaniati, Poppy, R. Metodologi Penelitian, Kuantitatif, Kualitatif, dan Campuran untuk Manajemen, Pengembangan, dan Pendidikan. Bandung: Refika Aditama (2014).

[6] Iwanger, Samuel, Ruth. \& Eriba, Joel. O. Effects of Competitive, Cooperative and Individualistic Classroom Interaction Strategies on Learning Outcomes in Basic Science. Case Studies Journal, Vol 7, Issues 7 (2018).

[7] Kanematsu, H. \& Barry, D.M. STEM and ICT Education in Intelligent Environments, London: Springer International Swizerland. p 34. (2016).

[8] Kenny, Dianna T. Direct instruction: An overview of Theory and Practice. Journal of the Association of Special Education Teachers. Vol 15. No.17 Desember. p 1. (1988).

[9] Nwabueze, Akachukwu I. \& Igbinedion, Doye A. The Implication of Cooperative Learning Strategy On Students Academic Achievements, African Journal of Education and Technology. Vol.3 (2013).

[10] Riqui Miguel de Cotto, Carvalho. Industri 4.0 Is Portugal Prepared For The Future . Disertation. Leiria: Polytechnic Institute of Leiria. p 2. (2017).

[11] Soyemi. J, Ogunyinka. O.I, Soyemi.O.B. Integrating Self-Paced E-Learning with Conventional Classroom Learning in Nigeria Educational System. Mediterranean Journal of Social Sciences. Vol 3 (2012).

[12] Uchemadu, Lazarus Kelechi, \& Ogundiya Ogunsola Gabriel. Effects Of Metacognition And Direct Instruction On Spelling Abilities Of Pupils With Learning Disabilities In Primary Schools In Ibadan, Oyo State. Nigeria. Europan Scientific Journal. Vol 12. No.1. January (2016).

[13] Watkins, Cathy L. Project Follow Through: A Case Study Of Contingencies, Influencing Instructional Practices Of The Educational Establishment. Beverly: Cambridge Center for Behavioral Studies. (1997).

[14] Weltman, David \& Whiteside, Mary. Comparing the Effectiveness of Traditional and Active Learning Methods in Business Statistics: Convergence to the Mean. Journal of Statistics Education.Volume 18. Number 1 (2017).

[15] Zhou. Molly, \& Brown. David. Educational Learning Theories. Goergia: Spring (2015). 